\title{
Comparison of Isthmus Detection Methods in the Apical Third of Mesial Roots of Maxillary and Mandibular First Molars: Macroscopic Observation versus Operating Microscope
}

\author{
Evangelos G. KONTAKIOTIS ${ }^{1}$ \\ Fotios D. PALAMIDAKIS ${ }^{2}$ \\ Eleftherios-Terry R. FARMAKIS ${ }^{1}$ \\ Giorgos N. TZANETAKIS ${ }^{1}$ \\ ${ }^{1}$ Department of Endodontics, Dental School, University of Athens, Athens, Greece \\ ${ }^{2}$ General Dentist, Private Practice, Athens, Greece
}

\begin{abstract}
The aims of this study were to assess the presence and the frequency of isthmuses in the mesial roots of the maxillary and mandibular first molars (at two resection levels from the apex), and to compare the findings obtained by macroscopic observation (MO) and operating microscope (OM). Forty maxillary and 40 mandibular mesial roots were observed at 3 and $5 \mathrm{~mm}$ from the apex initially macroscopically and then with the use of an OM. The presence of an isthmus and the number of root canals detected were recorded. Data were analyzed statistically by Fisher's exact test for isthmus evaluation and Wilcoxon signed rank-test for number of root canals at a confidence interval of $95 \%$. Comparison between MO and OM regarding the number of roots with isthmuses provided the following results: Mandibular group: At 3 mm level: MO 19 vs. OM 27; at 5 mm level: MO 31 vs. OM 32. Maxillary group: At 3 mm level: MO 9 vs. OM 14; at $5 \mathrm{~mm}$ level: MO 19 vs. OM 21. Significant differences $(\mathrm{p}<0.05)$ were found concerning the accuracy of the isthmus detection methods at both resection levels $(3$ and $5 \mathrm{~mm}$ ) and both types of roots, as well as for the number of the canals inspected under the $\mathrm{OM}$ between the two resection levels of the mesial roots of the maxillary first molars. Under the tested conditions, OM increased the diagnostic accuracy of isthmus detection at both resection levels and root types.
\end{abstract}

Key Words: Endodontic treatment, mandibular and maxillary first molars, isthmus, periradicular surgery, operating microscope.

\section{INTRODUCTION}

Isthmus is defined as a fine junction between two or more root canals coexisting in the same root (1). It mainly encloses pulp tissue (2), organic remnants and calcified areas (3) and should be considered as a very essential element of root canal space anatomy (2). The most frequent area to be revealed is the apical $5 \mathrm{~mm}$. As a result, isthmus occurrence is difficult and sometimes unable to be inspected $(2,4)$. Common similar expressions describing the term "isthmus" are lateral interconnection, corridor and transverse anastomoses (5).

Pulp space irregularities, such as isthmuses at certain levels across the root, increase the difficulty degree of root canal instrumentation and may have an impact on root canal treatment success (6).

Furthermore, isthmuses appear to be difficult to get approached by root canal instruments (2). Whenever bacteria or their byproducts gain entry inside the pulp space, it is inevitable that they reach isthmuses too (2). As a result, they act as bacterial reservoirs (2). Irrigating solutions and root filling materials are not likely to penetrate into these spaces (7). This is one of the reasons why a number of surgical or non-surgical endodontic treatments performed in a state-of-the-art fashion, result in failure $(2,4,8)$.

Isthmuses that are overlooked during periradicular surgery can also lead to failure (4). Nowadays, root-end resection followed by a proper isthmus preparation and filling is expected to increase the success rates of 
endodontic treatment in certain cases $(7,9,10)$.

The one and only prerequisite for the existence of isthmuses, as part of pulp space morphology, is at least two root canals running in a single root (II, III, IV Weine's categories). Therefore, mesial roots of mandibular first molars and mesiobuccal roots of maxillary first molars are by far the most common to reveal the presence of isthmuses $(4,7)$.

The aims of this in vitro study were to assess the presence and the frequency of isthmus in the mesial roots of maxillary and mandibular first molars (at two different resection resection levels from the apex), and to compare the findings between macroscopic observation (MO) and analysis with an operating microscope (OM).

\section{MATERIAL AND METHODS}

Forty maxillary and 40 mandibular, freshly extracted first molars were randomly selected and stored in distilled water. The patients' age, gender, and race were unknown. The identification of these teeth as maxillary or mandibular first molars was confirmed by accepted criteria (11). All distal roots as well as palatal roots of maxillary molars with the respective part of the crown were sectioned using a high-speed diamond (Isomet 11-1180; Buehler Ltd., Lake Bluff, IL, USA) under running tap water and discarded.

Each root was placed in $5.25 \%$ sodium hypochlorite for $24 \mathrm{~h}$ (in order to remove any organic debris). Then the specimens were numbered, embedded in self-curing acrylic resin blocks (Jet acrylic resin; Lang Dental MFG. Co., IL, USA) and subsequently sectioned perpendicular to the long axis of the root at $3 \mathrm{~mm}$ short of the apex using a high-speed diamond (Isomet 11-1180; Buehler Ltd.) under running tap water, rinsed thoroughly with sterile saline, subjected to $1 \%$ methylene blue staining (MBS) for $20 \mathrm{~s}$, rinsed shortly with pure alcohol and dried $(9,12,13)$.

The stained root surfaces were examined by three examiners (two endodontists and one general dentist) initially macroscopically from a standard $30-\mathrm{cm}$ sitting position without magnification, and then under an $\mathrm{OM}$ (Protégé Plus; Global Surgical, Inc., St. Louis, MO, USA) at $\times 3$ magnification (14). Recordings were the results of the agreement between all examiners or at least two. The exact number of root canals located at this level and the presence of an isthmus were recorded. The images from the OM were captured through a CCD camera and stored.
Then the resin blocks containing the roots were sectioned in a perpendicular direction at $5 \mathrm{~mm}$ short of the apex and the same staining, recording and evaluation procedures described before were done.

Data were analyzed statistically by Fisher's exact test for isthmus evaluation and Wilcoxon signed rank-test for number of root canals at a confidence interval of $95 \%$.

\section{RESULTS}

The results regarding the number of root canals (percent values) and the presence of isthmus at the resection levels with the two observation methods are illustrated in Tables 1 and 2.

Concerning the number of root canals running in the mesial roots of mandibular first molars, no significant difference was found in terms of the observation method at $3 \mathrm{~mm}$ short of the apex. At the level of $5 \mathrm{~mm}$, same percentages were recorded with both observation methods. As for the number of the root canals inspected at both resection levels when using the OM no statistically significant differences were found.

Regarding the isthmus frequency in the mesial roots of mandibular first molars, no significant difference was found, when the $\mathrm{OM}$ was used as the observation method comparing the two resection levels.

Table 1. Results for mesial roots of mandibular first molars.

\begin{tabular}{lcc}
\hline \multicolumn{3}{c}{ a. Distance from the apex: $3 \mathrm{~mm}$} \\
\hline & $\begin{array}{c}\text { Macroscopic } \\
\text { observation }\end{array}$ & $\begin{array}{c}\text { Operating } \\
\text { microscope }\end{array}$ \\
\hline 1 root canal & $12 / 30.00 \%$ & $11 / 27.50 \%$ \\
2 root canals & $27 / 67.50 \%$ & $26 / 65.00 \%$ \\
3 root canals & $1 / 2.50 \%$ & $3 / 7.50 \%$ \\
Total: & $40 / 100 \%$ & $40 / 100 \%$ \\
Isthmus & $19 / 47.50 \%$ & $27 / 67.50 \%$ \\
\hline & b. Distance from the apex: $5 \mathrm{~mm}$ \\
\hline & $\begin{array}{c}\text { Macroscopic } \\
\text { observation }\end{array}$ & $\begin{array}{c}\text { Operating } \\
\text { microscope }\end{array}$ \\
\hline 1 root canal & $3 / 7.50 \%$ & $3 / 7.50 \%$ \\
2 root canals & $37 / 92.50 \%$ & $37 / 92.50 \%$ \\
3 root canals & $-/-$ & $-/-$ \\
Total & $40 / 100 \%$ & $40 / 100 \%$ \\
Isthmus & $31 / 77.50 \%$ & $32 / 80.00 \%$ \\
\hline
\end{tabular}


On the other hand, significant differences were found concerning the type of isthmus inspection method, at both resection levels, with increased possibility for an isthmus to be inspected under the OM ( $3 \mathrm{~mm}$ : $\mathrm{p}<0.01$ - odds ratio $=24$; and $5 \mathrm{~mm}$ : $\mathrm{p}<0.01$ - odds ratio $=29$ ).

Although no significant difference was found regarding the number of the mesiobuccal mandibular root canals recorded at both resection levels no matter the mode of the observation, the p-value at the 3 $\mathrm{mm}$ level $(\mathrm{p}=0.0576)$ is suggestive of a correlation. Significant difference $(p<0.01)$ was found as to the number of the root canals revealed using the OM, with increased possibility for locating a second root canal at the level of $5 \mathrm{~mm}$, comparing the two resection levels $(\mathrm{p}<0.01)$.

The presence of isthmus was recorded at higher percentages at both resection levels under the use of an OM ( $3 \mathrm{~mm}: \mathrm{p}<0.01$ - odds ratio $=12$ and $5 \mathrm{~mm}: \mathrm{p}<0.01$ - odds ratio=9.2). Statistically significant difference was revealed concerning the percentages of the existence of an isthmus between the two resection levels using the $\mathrm{OM}$, in favor of the $5 \mathrm{~mm}$ level $(\mathrm{p}<0.05$ - odds ratio $=5.87$ ).

Table 2. Results for mesiobuccal roots of maxillary first molars.

\begin{tabular}{lcc}
\hline \multicolumn{3}{c}{ a. Distance from the apex: $3 \mathrm{~mm}$} \\
\hline & $\begin{array}{c}\text { Macroscopic } \\
\text { observation }\end{array}$ & $\begin{array}{c}\text { Operating } \\
\text { microscope }\end{array}$ \\
\hline 1 root canal & $25 / 62.50 \%$ & $22 / 55.00 \%$ \\
2 root canals & $15 / 37.50 \%$ & $16 / 40.00 \%$ \\
3 root canals & $-/-$ & $1 / 2.50 \%$ \\
4 root canals & $-/-$ & $1 / 2.50 \%$ \\
Total & $40 / 100 \%$ & $40 / 100 \%$ \\
Isthmus & $9 / 22.50 \%$ & $14 / 35.00 \%$ \\
\hline & b. Distance from the apex: 5 mm \\
\hline & Macroscopic & Operating \\
\hline observation & microscope \\
\hline root canal & $11 / 27.50 \%$ & $12 / 30.00 \%$ \\
3 root canals & $29 / 72.50 \%$ & $26 / 65.00 \%$ \\
Total & $-/-$ & $1 / 2.50 \%$ \\
\hline
\end{tabular}

\section{DISCUSSION}

The presence of isthmuses in the mesial roots of mandibular and maxillary first molars has been under investigation for over 40 years (1-5,7,8,10,15-19).

According to the literature, isthmuses are categorized to five groups $(2,4)$. Previous studies have investigated and analyzed isthmus occurrence by means of frequency, type or both in mesial roots of maxillary $(1,7,8,15)$ and mandibular $(2,3,7,15,17,18)$ first molars. The majority of these studies $(1,2,7,8,15,17)$ examined at the same time the number of the root canals appearing in mesial roots of the mandibular and maxillary first molars. The analysis was performed at 3 and $5 \mathrm{~mm}$ from the apex. This type of investigation has been done by other authors in order to reveal the presence of lateral canals in these roots $(4,5)$.

The most commonly used methods for in vitro isthmus identification are the use of a magnification system, such as an optical microscope $(1,4,5,15)$, a scanning electron microscope (8), a stereomicroscope (2), microphotographs (20), polyester casting resin replicas (17), and a microtomograph (20). In in-vivo situations, such as surgical endodontic treatment following apicoectomy, an endoscope (7) or a surgical OM(9) have been used.

Under the terms of this in vitro study, the resected root surfaces of the mesial roots of the mandibular and maxillary first molars were examined macroscopically and with the use of an optical microscope. This kind of isthmus detection methodology at these types of roots has not been applied before.

According to the literature, isthmus frequency is reported to be highest at 4-6 $\mathrm{mm}$ short of the apex in the mesial roots of maxillary first molars and 3-5 mm short of the apex of mandibular molars $(1,4)$. Moreover, the apical third of a root is the area where endodontic apical surgery takes place. These are the main reasons why in the present study, the roots were resected 3 and $5 \mathrm{~mm}$ short of the apex.

The frequency of isthmus in the apical third, regardless of the exact inspection level, in the mesial roots of first molars varies between 6 and $83 \%$ for the maxillary molars $(4,7,17)$, and between 8 and $76 \%$ for the mandibular molars $(1,7)$. The percentages reported in this study are on the higher end for both types of teeth and in agreement with the previously mentioned studies.

Although no significant difference was found concerning the number of the mesiobuccal maxillary 
root canals recorded at both resection levels regardless of the observation method, the p-value at the $3 \mathrm{~mm}$ level $(p=0.0576)$ is suggestive of a correlation. More specimens would be needed in order to further investigate this hypothesis.

A review of the existing literature shows that all previous studies targeted on the identification of isthmuses, whereas the current study focused on simulating the clinical challenge produced by the present of isthmuses. The comparison of standardized macroscopic observation versus $\mathrm{OM}$ detection of the isthmuses revealed better results for the microscopic analysis.

In conclusion, under the conditions of the present study, OM was proven an essential tool in the field of endodontic apical surgery in order to increase isthmus detection accuracy and aid the subsequent treatment.

\section{RESUMO}

Os objetivos deste estudo foram avaliar a presença e a freqüência de istmos nas raízes mesiais de primeiros molares superiores e inferiores (em dois níveis de ressecção a partir do ápice), e comparar os achados obtidos por observação macroscópica $(\mathrm{OM})$ e microscópio operativo (MO). Quarenta raízes mesiais superiores e inferiores foram examinadas a 3 e $5 \mathrm{~mm}$ do ápice, inicialmente macroscopicamente e em seguida com o uso do MO. A presença de istmo e o número de canais radiculares detectado foram registrados. Os dados foram analisados estatisticamente usando o teste exato de Fisher para avaliação do istmo e o teste de Wilcoxon (signed rank-test) para o número de canais radiculares, com um intervalo de confiança de $95 \%$. A comparação entre OM e MO com relação ao número de raízes com istmos forneceu os seguintes resultados: Grupo mandibular: $3 \mathrm{~mm}$ : OM 19 vs. MO 27; 5 mm: OM 31 vs. MO 32. Grupo maxilar: 3 mm: OM 9 vs. MO 14; 5 mm: OM 19 vs. MO 21. Diferenças significantes $(p<0,05)$ foram encontradas com relação à precisão dos métodos de detecção de istmos em ambos os níveis de ressecção (3 e 5 $\mathrm{mm}$ ), e ambos os tipos de raízes, bem como quanto ao número de canais radiculares inspecionados sob MO entre os dois níveis de ressecção das raízes mesiais dos primeiros molares superiores. Nas condições testadas, MO aumentou a precisão diagnóstica na detecção de istmos em ambos os níveis de ressecção e tipos de raízes.

\section{REFERENCES}

1. Weller RN, Niemczyk SP, Kim S. Incidence and position of the canal isthmus. Part 1. Mesiobuccal root of the maxillary first molar. J Endod 1995;21:380-383.
2. Teixeira FB, Sano CL, Gomes BPFA, Zaia AA, Ferraz CCR, Souza-Filho FJ. A preliminary in vitro study of the incidence and position of the root canal isthmus in maxillary and mandibular first molars. Int Endod J 2003;36:276-280.

3. Mannocci F, Peru M, Sherriff M, Cook R, Pitt Ford TR. The isthmuses of the mesial root of mandibular molars: a microcomputed tomographic study. Int Endod J 2005;38:558-563.

4. Hsu Y, Kim S. The resected root surface: the issue of canal isthmuses. Dent Clin North Am 1997;41:529-540.

5. Pineda F. Roentgenographic investigation of the mesiobuccal root of the maxillary first molar. Oral Surg Oral Med Oral Pathol 1973;36:253-260.

6. Schilder H. Cleaning and shaping the root canal. Dent Clin North Am 1974;18:269-296.

7. Von Arx T. Frequency and type of canal isthmuses in first molars detected by endoscopic inspection during periradicular surgery. Int Endod J 2005;38:160-168

8. Tam A, Yu DC. Location of canal isthmus and accessory canals in the mesiobuccal root of maxillary first permanent molars. J Can Dent Assoc 2002;68:28-33.

9. Stropko JJ, Doyon GE, Gutman JL. Root-end management: resection, cavity preparation, and material placement. Endod Top 2005;11:131-151.

10. Degerness R, Bowles W. Anatomic determination of the mesiobuccal root resection level in maxillary molars. J Endod 2008;34:1182-1186.

11. Sicher H, DuBrul EL. Oral anatomy. 6th ed. St. Louis: CV Mosby, 1975. p 236-239.

12. Cambruzzi JV, Marshall FJ, Pappin JB. Methylene blue dye. An aid to endodontic surgery. Endo Report 1985;11:311-314.

13. Wright HM, Loushine RJ, Weller RN, Kimbrough WF, Waller J, Pashley DH. Identification of resected root-end dentinal cracks: A comparative study of transillumination and dyes. J Endod 2004;30:712-715.

14. Kontakiotis EG. The operating microscope: A unique tool in Endodontology. Pract Proced Aesthet Dent 2008;20:8-9.

15. Jung I-Y, Seo M-A, Fouad AF, Spångberg LSW, Lee S-J, Kim H-J. Apical anatomy in mesial and mesiobuccal roots of permanent first molars. J Endod 2005;31:364-368.

16. Rocha LF, Sousa Neto MD, Fidel SR, Da Costa WF, Pécora JD. External and internal anatomy of mandibular molars. Braz Dent J 1996;7:33-40.

17. Skidmore AE, Bjørndal AM. Root morphology of the human mandibular first molar. Oral Surg Oral Med Oral Pathol $1971 ; 32: 778-784$.

18. Gu L, Wei X, Ling J, Huang X. A microcomputed tomographic study of canal isthmuses in the mesial root of mandibular first molars in a Chinese population. J Endod 2009;35:353-356.

19. Pécora JD, Woelfel JB, Sousa Neto MD, Issa EP. Morphologic study of the maxillary molars. Part II: Internal anatomy. Braz Dent J 1992;3:53-57.

20. Cambruzzi JV, Marshall FJ. Molar endodontic surgery. J Can Dent Assoc 1983;49:61-65 